\title{
EDITORIAL
}

\section{Advances in education: from the Egyptian papyrus roll to signature pedagogies of the digital era}

\author{
Editor-in-Chief: Sergei Abramovich
}

What is education? It appears that there is no definitive answer to this seemingly simple question. Even such legendary theorists of American education as John Dewey and Edward Thorndike define education quite differently. Whereas for Dewey ${ }^{[1]}$ education is a method by which one studies the world, Thorndike ${ }^{[2]}$ sees education as the production and prevention of changes. This brief editorial is not to compare and contrast different definitions. Rather, the goal is, through alluding to major contributors to the field of education over several millennia span, to try to outline the scope and aims of the journal. Setting up such an outline based on the historical account of education, is consistent with the position of the modern-day Brazilian educator Paulo Freire who sees education as "revolutionary futurity ... which corresponds to the historical nature of humankind ... affirms women and men as beings who transcend themselves ... for whom looking at the past must only be a means of understanding more clearly what and who they are so that they can more wisely build the future" ${ }^{\text {[3] }}$. Indeed, many pedagogical ideas of the past can be recognized as having been revisited in various contemporary educational contexts.

The Egyptian papyrus roll (circa 1650 BC)

Received: Sept. 24, 2019; Accepted: Sept. 25, 2019; Published: Sept. 26, 2019 Correspondence to: Sergei Abramovich, State University of New York at Potsdam, USA; Email: abramovs@potsdam.edu

Citation: Abramovich S. Advances in education: from the Egyptian papyrus roll to signature pedagogies of the digital era. Adv Educ Res Eval, 2019, 1(1): 1-5.

Copyright: (1) 2019 Sergei Abramovich. This is an open access article distributed under the terms of the Creative Commons Attribution License, which permits unrestricted use, distribution, and reproduction in any medium, provided the original author and source are credited. found in the $19^{\text {th }}$ century by Henry Rhind, a Scottish scholar and collector of antiques, may be considered being the first source of educational information where methods of finding areas of simple geometric figures were recorded by Ahmes, an Egyptian scribe ${ }^{[4]}$. A millennium later, another record is due to a Chinese philosopher Confucius (551-479 BC) who saw education through social lenses so that teaching is an activity through which both teachers and students develop, and learning is a process inseparable from thinking which, in turn, implies learning ${ }^{[5]}$. Approximately at the same time, a Greek philosopher Pythagoras (570-495 BC) and his disciples made many discoveries in mathematics and science that are still taught today in the schools around the world. It is the discovery of irrational numbers that was used by Plato (428-348 BC) in describing the first dialogue ${ }^{[6]}$ between Socrates (470-399 BC) and his interlocutor when the former asks how the two-fold increase of area of a square affects the change of its side length; a question, while was not answered correctly by the latter, at that time, did not have the right answer in exact arithmetical terms because the side length of the larger square is not a rational number. To put this question in the modern-day educational context, when there exist the student evaluation standards ${ }^{[7]}$, one might be curious whether asking a question with no correct answer satisfy such standards designed not to harm students, especially in high-stakes situations. Notwithstanding, in this dialogue, which came to us from the two 
giants of ancient Greek philosophy, one can see the early confluence of mathematics and psychology. Indeed, the interlocutor tried to use previously learned problem-solving strategy in a situation to which this strategy is not applicable due to the transition from rational to irrational numbers, something that Gestalt psychologists of the $20^{\text {th }}$ century referred to as Einstellung effect ${ }^{[8]}$.

When, in the true spirit of John Dewey's conceptualization of education, one studies the world, one learns. In turn, educational psychology studies how humans learn. Through those studies, knowledge about patterns of cognitive development, effective means to motivate learning, and the relationship between teacher and student, is generated. In particular, over many centuries span, due to the contribution of the ancient Greek philosophers, especially by Aristotle (384-322 BC), student of Plato, educational theorists studied the effect of visual thinking on the development of an individual because, as Aristotle put it, "the soul never thinks without an image"[9]. Thus, the journal welcomes submission of papers on educational applications of mathematics, philosophy, psychology, sociology and history, both as separate subjects and in any relevant combination.

In the middle ages, the field of education was significantly advanced by a Persian polymath Avizenna (980-1037) who is considered the most significant thinker of the pre-modern era and the father of modern medicine. Avizenna, like other great thinkers before him, conceptualized education as a blend of social growth and cognitive development of an individual, be it a child or an adult $^{[10]}$, thereby connecting psychology and sociology to education. In the late modern period of the $18^{t h}$ century Europe, a Genevan philosopher Jean-Jacques Rousseau (1712-1778) emphasized the importance of visual thinking in (elementary) mathematics ${ }^{[9]}$, something that is encouraged by the modern-day educational documents around the world, including England ${ }^{[11]}$,
Singapore ${ }^{[12]}$ and the United States ${ }^{[13]}$, to name just a few countries. A Swiss reformer of education Johann Pestalozzi (1746-1827) introduced the idea of teaching as a two-fold task: to help an individual to develop cognitively and to address the social dimension of the individual ${ }^{[14]}$. Once again, education was directly connected to cognitive and social issues. Furthermore, Pestalozzi can be credited for what in the age of computers is called digital fabrication ${ }^{[15]}$ as he encouraged his students to draw different geometric images like angles, triangles, rectangles, and so on ${ }^{[9]}$. Nowadays, such drawings can be carried out by computers. This links education to computer science, the educational aspects of which are within the scope of the journal as well.

The issue of motivation in the context of education has received new impetus at the turn of the $20^{\text {th }}$ centuty. William James, academic grandfather of John Dewey, wrote the first book on psychology for teachers. In his book he encouraged teachers to motivate students by focusing on topics and ideas that are within their interests. As James ${ }^{[16]}$ put it, "Any object not interesting in itself may become interesting through becoming associated with an object in which an interest already exists". Motivation through liberty to learn can be seen in an Italian educator Maria Montessori's approach to the education of young children inquiring "should not the child ... some day brace himself to a real effort, compelling him to carry out a necessary, rather than a chosen, task?"[17]. Similarly, a Japanese philosopher of education Tsunesaburo Makiguchi argued that teachers should be "channeling student efforts into better ways of formulating ideas for themselves" ${ }^{[18]}$ in order to support students' interest in learning, something that may never be neglected or restrained. By asserting that the ownership of an idea facilitated by a teacher makes a student feel happy, Makiguchi demonstrated that his educational approach was in full agreement with that put forward by Montessori. Put an- 
other way, tools of sociology, psychology and philosophy motivate the advancement of educational ideas around the world.

The journal will be interested to publish papers dealing with educational issues associated with the notion of collateral learning ${ }^{[1]}$, something that does not result from the immediate objective of the curriculum under study but rather stems from its hidden domain. In a more general context, the notion of collateral learning brings to mind another educational construct known as hidden curriculum - "those nonacademic but educationally significant consequences of schooling that occur systematically"[19]. This kind of learning experience is taking place within a context that is much broader than a topic of any given lesson and, through reflection, enables students to become aware of rules and guidelines typically associated with social relations and control of individual actions. Papers on the topics of collateral learning and hidden curriculum across different subject matters are welcome. Another area of interest deals with the pedagogy of action learning that has been traditionally used for teaching business management ${ }^{[20]}$, the social sciences ${ }^{[21]}$, teacher development ${ }^{[22]}$, mathematics education ${ }^{[23]}$ and conducting scientific research ${ }^{[24]}$. Action learning can be described as a problem-solving method through which one takes an action and reflects on the results of this action. It is through such reflection that collateral learning opportunities become available and hidden domains of academic curricula can be revealed. In the digital era, both action and reflection can be supported by ubiquitous computers. This brings us to another important domain of interest for the journal associated with technological advances from which the modern-day education benefits, provided that such advances are used in the classroom appropriately.

It has been more than half a century since the idea of extending the use of computers from largescale research computations to educational con- text was put forward. The teaching machine movement has its roots in the work of Pressey ${ }^{[25]}$ who believed that "mechanical aids are possible which... would leave the teacher more free for her most important work, for developing in her pupils fine enthusiasms, clear thinking and high ideas". These pioneering beliefs about automated instruction, while being limited to research at Ohio State University in the 1920s, over the next three decades evolved into a major research and development program sponsored by the United States Air Force ${ }^{[26]}$. Skinner ${ }^{[27]}$, seeing the use of teaching machines as a response to increased demand throughout the world for a highly qualified workforce, called for education to "become more efficient [by allowing each student] to take an active role in the instructional process" and, through the use of technology, "to proceed at his own level, advancing as rapidly as he can". A history of the teaching machine movement, when compared to today's perspectives on the educational applications of modern computers, including the theory of instrumental genesis ${ }^{[28]}$ with its origin in the seminal ideas by Vygotsky ${ }^{[29]}$ about mediating cognitive processes by technical devices and psychological tools, indicate pedagogical insight by the movement's proponents and their acumen in predicting the development of education worldwide.

Nowadays, the use of computers in education is considered as a kind of signature pedagogy integrated across the variety of disciplines. Using the contexts of medical, engineering and law schools as examples, Shulman ${ }^{[30]}$ introduced the notion of signature pedagogy towards the end of developing in students the habits of mind of professionals working in the field they are preparing to join. Common characteristics for all signature pedagogies varying across the disciplines comprise surface, deep and implicit structures of teaching. In particular, within the deep structure of teaching teachers and students can become 'partners in advancement ${ }^{\text {'[31] }}$ by exploring jointly gener- 
ated questions. This educational idea of teacherstudent partnership through teaching was already dear to Confucius some 25 centuries ago. In the modern-day classroom, the teacher-student partnership includes interaction through the process of formative assessment, something that provides a teacher with information of how to adapt classroom instruction to increase students' achievement and enable their future learning ${ }^{[32]}$. Furthermore, seeing the use of computers as a signature pedagogy common across a variety of disciplines raises the question of how to evaluate students when almost everything is available on-line and can be easily copied from the Internet and pasted into one's homework assignment without understanding. Discussion of these aspects of teacherstudent partnership in the context of evaluation and on-line materials used with (and/or without) understanding will be a welcome feature on the pages of the journal.

The journal Advances in Educational Research and Evaluation is a peer reviewed open access journal aimed to be a medium for the discussion of a wide range of international educational experiences and assessment techniques. The Journal intends to publish high quality articles the scope of which includes, but is not limited to, topics mentioned in this editorial. With support of international team of educational scholars who kindly volunteered to serve on the editorial board, the Journal is set to adhere to the highest standards of publishing ethics.

\section{References}

[1] Dewey J, 1938, Experience and Education, Kappa Delta Pi, New York.

[2] Thorndike EL, 1912, Education: A First Book, MacMillan, New York.

[3] Freire P, 2003, Pedagogy of the Oppressed, Continuum, New York.

[4] Chase AB, Manning HP and Archibald RC, 1927, The Rhind Mathematical Papyrus, British Museum 10057 and 10058, vol. 1, Mathematical Association of America, Oberlin, $\mathrm{OH}$.
[5] Dai Q and Cheung KL, 2015, The wisdom of traditional mathematics teaching in China, in How Chinese Teach Mathematics, World Scientific, Singapore, 3-42. https://doi.org/10.1142/9789814415828_0001

[6] Gulley N, 1962, Plato's Theory of Knowledge, Methuen, London.

[7] Gullickson AR, 2002, The Student Evaluation Standards: How to Improve Evaluations of Students, Corwin Press, Thousand Oaks, CA.

[8] Luchins AS, Mechanization in problem solving: The effect of Einstellung. Psychological Monographs, 1942, 54(6): 195. https://doi.org/10.1037/h0093502

[9] Arnheim R, 1969, Visual Thinking, University of California Press, Berkeley and Los Angeles.

[10] Nejad MB, Rashidi M and Oloumi MM. Avicenna's educational views with emphasis on the education of hygiene and wellness. International Journal of Health Policy and Management, 2013, 1(3): 201-205.

https://doi.org/10.15171/ijhpm.2013.37

[11] Department for Education, 2013, National Curriculum in England: Mathematics Programmes of Study, viewed on September 20, 2019.

https://www.gov.uk/government/publications/nationalcurriculum-in-england-mathematics-programmes-of-study

[12] Ministry of Education Singapore, 2012, Mathematics Syllabus: Secondary One to Four. Normal (Technical) Course. Curriculum Planning and Development Division, viewed on September 20, 2019. https://www.moe.gov.sg/education/syllabuses

[13] Common Core State Standards, 2010, Common Core Standards Initiative: Preparing America's Students for College and Career, viewed on September 20, 2019. http://www.corestandards.org

[14] Horlacher R. Vocational and liberal education in Pestalozzi's educational theory. Pedagogia Y Saberes, 2019, 50: 109-120. https://doi.org/10.17227/pys.num50-9504

[15] Gershenfeld N, 2005, Fab: The Coming Revolution on Your Desktop - From Personal Computers to Personal Fabrication, Basic Books, New York.

[16] James W, 1983, Talks to Teachers on Psychology, Harvard University Press, Cambridge, MA.

[17] Montessori M, 1917, Spontaneous Activity in Education, Frederick A. Stokes Publishers, New York.

[18] Makiguchi T, 1989, Education for Creative Living, Iowa State University Press, Ames, IA.

[19] Martin J, 1983, What should we do with a hidden curriculum when we find one?, in The Hidden Curriculum and Moral Education: Deception or Discovery?, McCutchan, Berkeley, CA, 122-140.

[20] Revans RV, 1982, The Origin and Growth of Action Learning, Chartwell-Bratt, Brickley, England.

[21] Naftalin I. Action learning in higher education. Educational Management and Administration, 1996, 24(2): 193-205. https://doi.org/10.1177/0263211X96242007

[22] Biggs J, 2003, Teaching for Quality Learning at University: What the Student Does, The Society for Research into Higher Education \& Open University Press, Philadelphia, PA. 
[23] Abramovich S, Grinshpan AZ and Milligan DL. Teaching mathematics through concept motivation and action learning. Educational Research International, 2019, ID 3745406: 13 https://doi.org/10.1155/2019/3745406

[24] Greenwood D and Levin M, 2007, Introduction to Action Research, 2nd edn, Sage Publications, Thousand Oaks, CA.

[25] Pressey SL. A simple apparatus which gives tests and scores - and teaches. School and Society, 1926, 23(586): 373-376.

[26] Lumsdaine, AA, 1960, Teaching machines: an introductory overview, in Teaching Machines and Programmed Learning: A Source Book, Department of Audio-Visual Instruction, National Education Association of the United States, 5-22.

[27] Skinner BF. Teaching machines. Science, 1958, 128(3330): 969-977. https://doi.org/10.1126/science.128.3330.969

[28] Rabardel P, 1995, Les Hommes et les Technologies, une Approche Cognitive des Instruments Contemporains [Men and Technologies, a Cognitive Approach to Contemporary Instruments], Armand Colin, Paris, France.

[29] Vygotsky LS, 1930, The instrumental method in psychology (talk given in 1930 at the Krupskaya Academy of Communist Education), Lev Vygotsky Archive, viewed September 20, 2019.

https://www.marxists.org/archive/vygotsky/works/1930/ instrumental.htm

[30] Shulman LS. Signature pedagogies in the professions. Daedalus, 2005, 134(3): 52-59. https://doi.org/10.1162/0011526054622015

[31] Bruner J, 1985, Vygotsky: A historical and conceptual perspective, in Culture, Communication, and Cognition: Vygotskian Perspectives, New York, Cambridge University Press, 21-34

[32] Wiliam D, 2011, Embedded Formative Assessment, Solution Tree Press, Bloomington, IN. 